\title{
Reconstructing Collaborative Economy In Indonesia By Implementing Takaful Ijtima’ $i$ Insurance System
}

\author{
Gemala Dewi \\ Department of Civil Law \\ Universitas Indonesia \\ Depok, Indonesia \\ gemalafillah@gmail.com
}

\author{
Zaitun Abdullah \\ Department of Islamic Law \\ University of Pancasila \\ Jakarta, Indonesia \\ itun.abdullah@gmail.com
}

\begin{abstract}
The Collaborative Economy has been understood to be in condition when products, services, and market relationships have changed as sharing startups impact business models. It is growing fast in various subjects including in financial needs where people called as crowdfundings. To avoid disruption, companies must adopt the Collaborative Economy Value Chain, which in sharia business can be taken from Islamic teachings. In the history of Islam at the early 7 th century, the Islamic state has found a "social security system" which they call as takaful ijtima'i. The Social security in Islam (takaful ijtima'i) is a social obligation (fardhu kifayah), which brings responsibility for muslims, as far they are able, to help each other, and state, as public entity, has a duty to ensure that such responsibility is implemented properly in any aspect including in private business. Inside at-takaful institution contained the spirit to help each other as part of whole society. Then, the spirit to help each other was made become a basic principle in sharia insurance institution (at-takaful al-ijtima'i). In its concept and practice, takaful ijtima'i system, for Indonesia context, could potentially be developed further. How the takaful ijtima'i can be as an alternative insurance system to reconstructing collaborative economy in Indonesia, is the problem that will be elaborated in this paper. This paper will focus on takaful ijtima' $i$ with wakaf and musyarakah model, and it will be seen and placed as alternative sharia insurance system in the future, especially in Indonesia context. With the protecting each other characteristic has been used as basic principles in institutions, can be seen that the system called sharia insurance or at-takaful al-ijtima'i.or Takaful Ijtima'i can be used as an alternative insurance system to reconstructing collaborative economy in Indonesia.
\end{abstract}

Keywords-collaborative economy; takaful ijtima'i; islamic insurance system, social justice

\section{INTRODUCTION}

By the growth of Islamic finance in Indonesia, the use of Sharia principles not only cope with the concept of finance in traditional economic business. Sharia system also covers other business including in collaboratiave economy or can be called as sharing economy. The collaborative economy is an economic model where ownership and access are shared between corporations, startups, and people. Indonesia has been the birth of home-grown sharing platforms in Islamic compliance, such as "Ojek Syar'i", a startup that provides a platform for motorbike ride sharing, which provides an online booking service for Muslim female motorbike taxi drivers which was started since 2013. Estimated about $87 \%$ of Indonesians are likely to use products or services from others in a share community, compared to $66 \%$ of the global population, according to a survey conducted by Nielsen in 2014.

This condition can be accepted because of the sharing economy offers a number of advantages: lower prices, stronger communities, a greater number of players in the market, and greater access to services that were once regarded as a luxury. It allows consumers to fully utilise excess or idle resources, and to access resources without necessarily purchasing or owning them. Globally, the sharing economy has grown faster than Facebook, Google, and Yahoo combined, and is growing rapidly by 2016 the revenue of sharing economy was projectedly until $\$ 335$ billion, equal to that of the traditional economy (World Economic Forum, 2016) .

By the rapid development of sharing economy in Indonesia these days, this paper would like to introduce about the concept of Takaful Ijtima' $i$ in the alternative system of sharia insurance which would be suficient to reconstruct collaborative economy in the field of insurance that can be more suitable to Islamic principle. Hopefully, this concept could also profitable to maximize the realization of social justice principle in Indonesia's Insurance system.

Social justice in Islam known as "takaful ijtima'i." The meaning of takaful ijtima' $i$ is giving a decent living standard for every citizen. Social justice is not just food, but also housing, education, health, and clothing (Rahman 2003). According to Harry Calvert, social justice is the main legitimate mechanism pertaining to the provision of security for sufficient individual income, if its implementation conducted by using other social services, to ensure someone meet the standard of minimum living that culturally acceptable (Rahman 2003).

In terms of law classification, its existence is included in fardhu kifayah (Jaribah 2006), it means that every muslim has an obligation to help others as far as their ability, meanwhile the state plays the role in the implementation to make it functioning well. These roles reflect the state capacity as the 
authority to force every individual under their power to implement Islamic law. Therefrom, social justice is not merely the state duty, but also a duty for every muslim to relieve the burden of a fellow human being.

In fiqh Umar, Jaribah wrote that this social justice caretaker consist of individual, society and the state. The state main duty is to manage this social justice system, but in the implementation, individual and society can take parts. This matter according to the Rasulullah S.A.W. Hadith, "Muslim is like a building that established each others" (Jaribah 2006; Rahman 2003).

\section{PROBLEM}

According to Syekh Abu Zahra, al-takaful al-ijtima'i meaning is every people in the society are guarantee under their society pledge (Zahrah s.a.). Therefrom can be understood, that at-takaful refer to the characteristic of protecting each other in the society. Protecting each other characteristic has been used as basic principles in institutions called sharia insurance or at-takaful (al-ijtima'i). Since, Takaful ijtima'i concept is very dynamic, so in current practices, it could be modified and mixed with others economy and law instruments. This includes when it could be modified and mixed with current sharia insurance system to provide the best alternative of social justice program for people by reconstructing the collaborative economy system. How the takaful ijtima'i can be applied in Shariah insurance system as an alternative insurance in reconstructing collaborative economy in Indonesia is the problem of this paper.

\section{METHOD}

Based on the research objectives to be achieved in this writing, Then the method that is considered appropriate is the method of doctrinal research. The Doctrinal legal research is, " Research that works to find the correct answers by verifying the truth sought in or from legal prescriptions written in the books of the law or religious books and the doctrines and underlying doctrines."

The Consideration of the use of the method because the starting point of this research is an analysis of existing sharia insurance concepts and run in Indonesia, including research on the principles and norms of sharia law in law that is universal and insurance law in positive law of Indonesia. The Particularly is against something specified in the insurance policy contract that is expected to give justice to the parties. Similarly, research on the accuracy of the use of insurance models and contracts used in Indonesia, as well as the correlation of its needs with the fatwas issued by DSN MUI.

In this doctrinal law research, the data used is secondary data, and the secondary data consists of 3 (three) kinds of legal materials, namely primary, secondary and tertiary law materials.

\section{TAKAFUL IJTIMA'I: CONCEPT AND HISTORICAL BACKROUND}

One of the Messenger's mission is to maintain social justice in the world, and it is reflected in Al Qur'an, Surah Al-Hadid [57]: 25. Based on the mission, therefore Rasulullah introduced social security system in Islam, which then by His successor (Khalifah) known as takaful ijtima'i.

From history aspect helping pattern in this takaful ijtima'i already existed in Arab culture before Islam. This concept then also implemented by Khulafa ar-Rasyidin until Khalifah Umar bin Abdul Aziz. However, they just started to build takaful ijtima'i institutionally in the era of Khalifah Umar ibn AlKhattab.

Takaful concept first used by Rasulullah when facing a murder case of two persons of Huzail tribe and imposed a law, al-aqilah. Al-aqilah as law means the law that imposes the killer to pay some money, called "blood money (diyat)," as compensation to victim's family. (Haekal 1986; Nashor 2004; Aly 2005). At that time, Rasulullah considered that al-aqilah, which applied in jahiliyyah era, was a form of goodness and could be an example to everyone. Not just that, even Rasulullah adopted al-aqilah in Medina Charter (Maslehuddin 1999).

The social justice practiced at the Messenger era can be seen on economy policies that established in Baitul Mal, like zakat and ushr distributions to whom are entitled to received it accordance to Al-Quran, payment for the muslims that still a slave, payment for the people who accidently killed by muslim troops, and allowance payment for the poor.

After the death of the Messenger, Caliph Abu Bakar AshShiddiq, Umar ibn Al-Khatab, Ustman Ibn Affan, and Ali Ibn Abi Thalib (Khulafa ar-Rasyidin) still practiced the social security system as Rasulullah had done. But, all of them had different styles when implemented it (Al-Qardhawi 1972; Ja'farian, 2004; Amalia 2010).

From the history of takaful ijtima'i existence, insurance in institution form just started to known around the 19th century, when there western colonizations towards Islam. But, it does not mean that the subject invalid and are not allowed in Islamic law. Because in muamalah matter, the principle is dispensation to determine the laws as long brings good advantage to human life.

\section{SHARIA INSURANCE PRINCIPLES}

The purpose of insurance is to protect the participants from any risk that might happen. Sharia insurance that is the adaptation of conventional insurance agencies having the ultimate principle, which are ta'awanu 'ala al bir, wa al-takwa (mutual cooperation in virtue and righteousness) and al-ta'min (provide security) (Djazuli 2007). These purposes make the participants as a part of a big family, which guaranteed and 
taking risk to each other. With this goal the sharia insurance using takafuli (take each other risk) in its akad (transaction).

Besides the ta'awun (helping) principle there are some other principles: corporations, mutual responsible principle, mutual protection principle, justice principle, and also free from gharar, maysir and riba elements.

Gharar means uncertanity, risk, or danger. According to Ali Adnan Ibrahim, gharar is (Ibrahim 2008):

"Excessive uncertainty or ambiguity generally includes lack of complete information, deceit, risk, and inherent uncertainty as to the subject matter of the contract. Uncertainty about future events and quality of goods may also be included, whether any particular incompleteness is unilateral, bilateral, multilateral, intentional, or otherwise."

Islam forbids every transaction that inside it occurs imbalance between risk and profits. In other words, Islam prohibits every transaction produce benefits without the willingness of bear loss (Al-Kamil s.a.).

Gharar in insurance can be seen from the form of contract (akad) that provides the basis of closure policy. In conventional life insurance, use tabadduli (exchange) contract. In sharia, exchange contract must be clear on the amount of which have to be paid and the amount that received. This condition made it confuse (gharar).

Maysir or gambling element must be avoided too. Maysir is every muamalah (transaction) that involved people with possibility of loss or profit (Hosen 1987). Allah forbids every gambling action as mention in Surah Al-Baqarah [2]: 219 and Al-Maidah [5]: 90, in that verse Allah called masyir as the work of satan. Maysir emerged as effect of uncertainty. In insurance, there three posibilities maysir happens (Jatmika 2007):

a. If policy holder experience misfortune although had just pay limited amount, the company have to bear the difference between the amount that paid and the amount insured. In this matter, the client benefited.

b. If until the end of agreement something does not occur while the client has pay out, so company that benefited.

c. If the client resigning before certain time limit (reserving period), will receive refunds in very small quantities, even in some companies considered scorched.

Riba is also prohibited in Islam. According to Barbara L. Seniawski, riba means "excess, increase, augmentation, expansion or growth" (Seniawski 2001). In terminology, riba defined as profits without any contract of value that has required by one of the party who hold the contract in interchanging two types of the goods, which has same values (Schacht 2010).

Riba could emerge from the investment runs by insurance companies. Basically, insurance companies similar to banks, which is both collecting people funds. These funds will be invested, so will gain profits. But, the problem is the investement instruments that practiced by the conventional insurance do not paying attention to the halal or haram matter on the form of the investment. So it was causing a concern that it might drown to the investment that base on interest (riba).

\section{HYBRID CONTRACT IN SHARIA INSURANCE}

According to these Fatwa DSN MUI on Sharia Insurance, namely Fatwa No. 21/DSN-MUI/X/2001 on Sharia Insurance Basic Guidance, Fatwa No. 51/DSN-MUI/III/2006 on Mudharabah Musytarakah Akad, Fatwa No. 52/DSNMUI/III/2006 on Wakalah Bil Ujrah Akad, and Fatwa No. 53/DSN-MUI/III/2006 on Tabarru' Akad, there are known four insurance contracts that produced four types of insurance. Those contracts are:

1. Tabarru';

2. Mudharabah;

3. Mudharabah musytarakah;

4. Wakalah bil ujrah.

The four sharia insurance contracts applied in the form of hybrid or double (al-uqud al-murakkabah), namely the merger of two types of akad that different due to the law, in this case the combination of between Tijari akad (tijari contract) and Tabarru' akad (tabarru' contract).

Tijari contract are represented by the akad mudharabah musytarakah, mudharabah or akad wakalah bil ujrah, while Tabarru' akad represented by akad hibah. Between Tijari akad (mudharabah musytarakah, mudharabah or wakalah bil ujrah) with tabarru' (hibah) have different characteristic and puposes.

Tabarru' Akad produced hibah type, and have the characteristic and purpose to help among insurance members, therefore must always there in every transaction of sharia insurance. Tabarru' Akad have a charateristic not to seek profits, so the Tabarru' akad can always combine with another Tijari Akad, namely wakalah bil ujrah or mudharabah musytarakah. This Tijari akad has charateristic and purpose to seek profits (profit oriented).

The different characteristic and purpose of the two akad are implicated in financial management that have be doing by the insurance company, funds separations.

Tabarru' means charity or doing a good without any requirements (Sumanto et al. 2009). Tabarru' Akad is the main akad, and have to inherent in every sharia insurance, as written in Fatwa DSN MUI No. 53/DSN-MUI/III/2006, part two.

Tabarru' Akad is a contract done between participants that contribute insurance that each participant must agree to help each other to take the risk if one of the participants have unfortunate event. The way of each participant giving contribution funds is that called tabarru' funds. The concept of taking risk like this called risk sharing. This type of akad can eliminate qharar and maysir factors in the sharia insurance.

Tabarru'akad application can produce hibah (grants) model, but this hibah concept that use in sharia insurance is still 
debatable. The debate are around the issue of wheter may or may not the funds that been grants readmitted, in a form of benefits or form of funds. This is as applied in sharia insurance, where the insurance participants still can get benefits from the grants in form of restitution when they get unfortunate event or repayment some of the grants when the ufortunate event did not happen.

The provision regarding the grants that contained in the Compilation of Islamic Law (Kompilasi Hukum Islam), Article 171 point $\mathrm{g}$, is:

"Hibah is a provision of an object voluntarily and without reward of a person to others who are still alive to possess." Article 212 KHI also regulates that, as stated too in Hadith, "Hibah can not retract, except hibah from parent to children."

The concept is different from the hibah concept that is practiced in the sharia insurance in Indonesia. Thoroughly the concept, there are several types of hibah. One of them is hibah with returns, not hibah that only expect Allah pleasure and without expecting any return. This type of hibah are allowed in Islam even has a different "degree" with the hibah that merely for Allah. Nevertheless, it is still in the corridor of Islamic law and constitutes of rukhsoh (waivers) in implementation of Islamic law. This type of hibah at least because of two reasons: firstly, because of the competition with conventional insurance; and secondly, because people was not yet had a good understanding about sharia economy, so the measure is always economic benefit factor.

Akad tijari that has been practiced is still using akad mudharabah and akad wakalah (bil ujrah). These two akad have advantage and disadvantage in the implementation. The advantage is the two contracts (akad) that most siutable use in Limited Company form of business, which are been acting as sharia insurance operator, because the operator does not have any loss risk over funds they managed. However, that is also as a disanvantage of the sharia insurance in Indonesia, which associated by the profit oriented business entity. That profit oriented business entity only wants to share the profit to the insurance participants, but does not want to handle the loss.

\section{PROPOSING WAKAF AND MUSYARAKAH MODEL IN TAKAFUL IJTIMA'I}

From the above descriptions, it is understandable that sharia insurance institution that exist in Indonesia has not yet accomplish cooperation purpose or helping each other base on justice. To maximize the achievement of helping principle in sharia insurance, there are several things that can be done, among others, using these akad, which more reflects the togetherness and helping spirit, namely akad wakaf and akad musyarakah.

The choosing of akad wakaf is because the wakaf has similar purpose with insurance, namely to help each other and reach common prosperity. The similarity can be an open door to wakaf system in insurance instrument.

Wakaf is also included in akad tabarru', and that akad is not for finding profits, but to help the people. Hibah and wakaf are included in akad tabarru', which both of them have some similarities and differences.

Majelis Tarjih dan Tajdid Muhammadiyah outlines several similarities and differences between hibah and wakaf, among others (Tim Fatwa Majelis Tarjih dan Tajdid Pimpinan Pusat Muhammadiyah 2009):

1. In wakaf and hibah there are people who give some of their wealth (wakif and wahib), the goods given, and people who receive it.

2. Wakaf goods are every goods, tangible or intangible that has durability that not only disposable and valued according to Islamic teaching, while hibah can be anything, disposable or durable. It is not allowed to wakaf or hibah the goods that forbidden to sell, like liabilities goods or haram things.

3. Wakaf goods only can be given to a group of people that can be use for the benefit of people, while hibah can be given to individual or group for benefit of people or only for individual.

In sharia insurance, the object of goods that given for wakaf for tabarru' is money, as mention in akad hibah, not things. The possibilitiy of wakaf objects that in form of money regulated in Article 16 clause (3) Act No. 41 Year 2004 on Wakaf. Besides that, MUI also had issued a Fatwa about cash wakaf in 2002 that said among others: the law for cash wakaf is jawaz (allowed); cash wakaf only can be distributed and use for matter that allowed by syari'i; and basic value of the cash wakaf have to guaranteed the sustainability, should not be sell, become the object of hibah and/or heritable.

Sharia insurance institution can be functioned as nadzir in cash money wakaf. Wakaf concept is the wakaf property should not decrease, should not perish, but productive and produce benefits, therefrom the main obligation of the sharia insurance institution is the same task as nazhir, which is to manage and develop wakaf property (Sula 2010).

Therefore then the wakaf funds should not be used for any other purpose, except have to be invested and managed first, and then the profit can be used. The use of investation funds are for claim funds and the fellowship operational which nisbah have already agreed. Also with the investation, should not be given to participant, but have to distributed and used for they who have rights (mauquf alaih) according to participant's will.

Position of customer while they pay the premiums is as someone that gives a wakaf (muwakif). Wakaf depends on purpose, and in this insurance, wakaf is for welfare of ummah, or wakaf for ta'awun. Therefore the role of "direction" from the muwakif intention is very important. And the most "appropriate" is wakaf for ummah welfare (al-waqf limaslahatil ummah) or wakaf for ta'awun (al-waqf lit ta'awun). So that the wakaf funds can be located for investment in assets provision to accomplish ummah welfare, which start from claim payment, operational cost, build hospital, school, even buildings that rented.

The concept can be used for sharia insurance with social based or non profit oriented insurance, or even for collective 
benefits. However, there is disadvantage in this wakaf institution, especially in price competition. With the two accounts that will be used, tabarru' account and saving account, automatically the participant will pay more amount than sharia insurance that using akad hibah. Nevertheless, this concept still can be implemented and very likely to be applied.

The advantages of sharia insurance concept based on akad wakaf as follows:

1. Assets will not decrease, even tended to increase, parrarel to the increase of customer and the passing of time.

2. The customer will get now and afterlife benefits in the time they pay the premiums, because when they pay the premiums they also doing wakaf for the welfare of ummah.

3. The result from the wakaf funds investation will add the reserve of tabarru' funds, also some part can be used to add sharia insurance company operational cost (nadzir).

4. Wakaf funds that collected can be use for wakaf asset, like wakaf building that can be use for sharia insurance office, or even can invest in to rented properties, like office buildings, that the investment results are for the customer interest.

To apply this concept in Indonesia is indeed require several preparations, not only normative preparation, but also the readiness of the people to accept the consequences. One of the change is the operator is not in the form of a limited company, but instead a mutual business entity. Mutual business entity in the form of resembles to partnership or what is called syirkah. Syirkah or musyakarah means mix, which is the mix one and the other, making it difficult to distinguished (Al-Dīn Muhammad s.a.).

In this matter syirkah is a form of collaboration between the owners of the capital to build a bigger business together, or cooperation between the capital owners who do not have skills to run a business with enterprenuer that do not have a capital or need additional capital. In the syirkah form of business like this, the akad that use is also syirkah or musyarakah. This syirkah is a part of tijari akad. This akad is also become a distinguishing factor between Limited Liability Company (Perseroan Terbatas) and Mutual Partnership (Persekutuan Perdata). This musyarakah arrangement has regulated in Fatwa DSN MUI No.8/DSN-MUI/IV/2000 on Musyarakah Financing.

Musyarakah or syirkah can be distinguished into several types, and among those types of syirkah, then syirkah inan is similar with mutual insurance type. Syirkah al-inan is a form of cooperation which two or more people where the parties are not the same capital and advantage portions and every party participated in the work (Hassan 1986; Djamil 2012; Chaudhry).

Further more Syafi'i explained that syirkah al-inan is a trade partnership that done by company that submit their property as capital and each member feasible to manage and develop the capital. Profits and risk are borne together. Syirkah model is the one that similar with mutual sharia insurance, and also in line with entity that regulated in Article 1618 Indonesian Civil Law (KUHPer).
DSN MUI through its Fatwa No. 08/DSN-MUI/IV/2000 on Musyarakah Financing in preamble states, “... musyarakah financing that has advantages in togetherness and justice, both in profit sharing and loss risk, now has been done by the Sharia Finance Institution (Lembaga Keuangan Syariah)." Even the Fatwa are not aimed specifically for sharia insurance, but generally can be use as guidance to run mutual sharia insurance business.

Justice element, as mentioned in the considerations, is proved by the existence of balance position on each party, balance in obligation and advantage, which implied in articles within Fatwa No. 08/DSN-MUI/IV/2000. This system can create the collaborative economy in islamic insurance system.

\section{CONCLUSION}

From the above discussions can be concluded that Takaful ijtima'i or social justice can be done by other parties besides the state. Insurance as a part of the takaful ijtima'i can be done by private parties with the purpose to help the state in manifesting social justice for the people in insurance activities. By this condition the collaborative economy could be applied by using Takaful Ijtima'i concept of Insurance that exercise Waqf and Musyarakah akad in running mutual sharia insurance business.

\section{REFERENCES}

[1] Abu Zahrah, Muhammad. (s.a.). Fi al-Mujtama al-Islamiy. Kahirah: Dar al-Fikr al Arabiy.

[2] Ahmad, Sheikh Mahmud. (2007). Economics of Islam. New Delhi: Adam Publishers and Distributors.

[3] Al-Basri, Ali al-Mawardi bin Muhammad. (1973). AlAhkam al-Sulthaniyah. Egypt: Mustafa al-Nani al-Halabi.

[4] Al-Dīn Muḥmmad, Jamāl ibni Mukarram. (s.a.). Lisan alArab, I. Beirut, Libanon: Dār Ihya al-Turathal-Arabi.

[5] Al-Haritsi, Jaribah bin Ahmad. (2006). Fiqih Ekonomi Umar bin Al-Khatab. Jakarta: Khalifa.

[6] Al-Kamil, Umar Abdullah. (s.a.). Al-Qowa'idul Fiqhiyyah al-Kubro wa Atsaruha fil Mu'amalat al-Maaliyah. Egypt: Jami'ah al-Azhar as-Syarif.

[7] Al-Qardhawi, Yusuf. (1969). Fiqh Az-Zakat, I. Beirut: Dar Al Irsyad.

[8] Al- Qardhawi, Yusuf. (1972). Hukum Zakat. Jakarta: Litera Antar Nusa.

[9] Aly, Khorshid. (2005). Islamic Insurance, a Modern Approach to Islamic Banking. New York: Routledge Curzon. 
[10] Amalia, Euis. (2010). Sejarah Pemikiran Ekonomi Islam dari Masa Klasik hingga Kontemporer. Depok: Gramata publishing.

[11] Djamil, Fathurrahman. (2012). Hukum Perjanjian dalam Transaksi di Lembaga Keuangan Syariah. Jakarta: Sinar Grafica.

[12] Djazuli. (2007). Fiqh Siyasah: Implementasi Kemaslahatan Umat dalam Rambu-Rambu Syari'ah. Jakarta: Kencana.

[13] Haekal, Muhammad. (1986). Sejarah Hidup Muhammad. Jakarta: Intermasa.

[14] Haji Hassan, Abdullah Alwi. (1986). Sales and Contracts in Early Islamic Commercial Law. Islamabad: Islamic Research Institute.

[15] Hosen, Ibrahim. (1978). Apakah Judi Itu. Jakarta: Lembaga Kajian Ilmiah Institut Ilmu Al-Qur'an.

[16] Ibrahim, Ali Adnan. (2008). Financial Innovations in the Muslim World. American University International Law Review, 23 (4).

[17] Ja'farian, Rasul. (2004). Sejarah Islam, Studi Kritis. Jakarta: Lentera.

[18] Jatmika, Agung. (2007). Asuransi Syariah. Paper presented at Airlangga University, Indonesia.

[19] Kettel, Brian. (2011). Introduction to Islamic Banking and Finance. United Kingdom: Willey.

[20] Maslehuddin, Muhammad. (1995). Menggugat Asuransi Modern. Jakarta: Lentera.

[21] Misra, Ramesh. (2000). Globalisation and the Welfare State. London: Mcmillan.

[22] Mubyarto. (1990). Sistem dan Moral Ekonomi Indonesia. Jakarta: LP3ES.

[23] Nassar, Mahmud Muhammad Mahmud Hasan. (2004). Shahih Bukhari. Beirut: Daar al-Kutub al-Ilmiyah.

[24] Rahman, Afzalur. (2003). Doktrin Ekonomi Islam. Yogyakarta: Dana Bhakti Wakaf.

[25] Sabahi, Babback. (2005). Financial Structures as Alternatives to International Loan Agreements: Challenges For U.S. Financial Institutions. Annual Review of Banking and Financial Law, 24.

[26] Schacht, Joseph. (2010). Pengantar Hukum Islam. Bandung: Nuansa.

[27] Seniawski, Barbara L. (2001). Riba Today: Social Equity, the Economy, and Doing Business Under Islamic Law. Columbia Journal of Transnational Law, 39.

[28] Soulaiman, Wan. (2008). Modern Approach of Zakat as an Economic and Social Instrument for Poverty Alleviation and Stability of Ummah. Jurnal Ekonomi dan Studi Pembangunan UMY, 9 (1). 